\title{
A rare case of herniated duplex collecting system causing obstructive uropathy
}

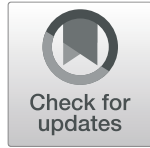

Christopher El Mouhayyar ${ }^{1,2^{*}}$ (D) Haoyang Wang ${ }^{1,2}$, Laith Hattar ${ }^{1,2}$, Fang-Yu Liu ${ }^{1,2}$, Karen Feghali, ${ }^{1,2}$ and

Vaidyanathapuram Balakrishnan ${ }^{1,2}$

\begin{abstract}
Background: An inguinal hernia is the protrusion of intraabdominal organs through an opening in the abdominal wall. Structures such as small and large intestines are commonly contained within inguinal hernias. However, uretero-inguinal hernia of the native collecting system is an extremely rarely reported entity. If unrecognized, acute kidney injury due to obstructive uropathy or serious intraprocedural ureteral injuries during hernia repair can occur. A duplex collecting system is a congenital kidney anomaly with an incidence of $0.8 \%$. A uretero-inguinal hernia involving duplicated ureters has not been previously described in literature. Here we report a case of obstructive uropathy secondary to uretero-inguinal hernia involving duplicated ureters.

Case presentation: A 78-year-old male known to have a left sided inguinal hernia presented to the Emergency department with two weeks of intermittent suprapubic tenderness, dysuria, frequency, urgency, frothy urine as well as nausea and vomiting. Workup on admission revealed an elevated creatinine of $2.8 \mathrm{mg} / \mathrm{dl}$. CT imaging revealed duplicated left sided ureters with left inguinal hernia containing the ureters. There was cystic ureteral dilation within the herniation sac as well as moderate left hydroureteronephrosis. Patient had an elective inguinal hernia repair with left ureteral stent placement. Following the surgery, he had recovery of kidney function to the previous baseline serum creatinine of $1.5 \mathrm{mg} / \mathrm{dl}$.

Conclusion: A duplex collecting system arises when two ureteral buds are formed during fetal development. However, diagnosis can be made in rare instances during adulthood when duplex collecting systems are usually found incidentally. Uretero-inguinal hernias have been reported as a common complication of renal transplant. However, uretero-inguinal hernias in native kidneys are considered an uncommon finding, especially with a duplex collecting system. When patients present with herniation and acute kidney injury, it is important to rule out the possibility of uretero-inguinal hernia to minimize complications such as obstructive uropathy and kidney failure. CT scan providing cross-sectional imaging is the ideal modality for identification of the site and etiology of urinary tract obstruction and site of herniation. If during imaging, an obstructive uropathy is observed, a nephroureteral stent or nephrostomy tube can be inserted to protect the ureter as well as relieve the obstruction, respectively.
\end{abstract}

Keywords: Uretero-inguinal hernia, Duplex collecting system, Acute kidney injury

\footnotetext{
* Correspondence: christopher.elmouhayyar@steward.org

'Department of Medicine, St. Elizabeth's Medical Center, Boston, MA, USA

2Department of Medicine, Tufts University School of Medicine, Boston, MA,

USA
}

(c) The Author(s). 2020 Open Access This article is licensed under a Creative Commons Attribution 4.0 International License, which permits use, sharing, adaptation, distribution and reproduction in any medium or format, as long as you give appropriate credit to the original author(s) and the source, provide a link to the Creative Commons licence, and indicate if changes were made. The images or other third party material in this article are included in the article's Creative Commons licence, unless indicated otherwise in a credit line to the material. If material is not included in the article's Creative Commons licence and your intended use is not permitted by statutory regulation or exceeds the permitted use, you will need to obtain permission directly from the copyright holder. To view a copy of this licence, visit http://creativecommons.org/licenses/by/4.0/ The Creative Commons Public Domain Dedication waiver (http://creativecommons.org/publicdomain/zero/1.0/) applies to the data made available in this article, unless otherwise stated in a credit line to the data. 


\section{Background}

An inguinal hernia is the protrusion of intraabdominal or extraperitoneal organs through an opening in the abdominal wall that is widely prevalent amongst male population [1,2]. A wide range of structures such as small bowel, large bowel and bladder are commonly contained within inguinal hernias. However, ureteroinguinal hernia is a rarely reported entity that is more frequently seen following a kidney transplant. Even further, uretero-inguinal hernias of the native kidneys have rarely been reported. This phenomenon is potentially associated with acute kidney injury due to obstructive uropathy or serious ureteral injuries if unrecognized prior to surgical hernia repair. A duplex collecting system is a common congenital kidney anomaly, with an incidence of $0.8 \%$ [3]. A uretero-inguinal hernia involving duplicated ureters has not been previously described in literature (Table 1). Here we report a case of obstructive uropathy secondary to uretero-inguinal hernia involving duplicated ureters.

\section{Case presentation}

A 78-year-old male with past medical history significant for CKD stage 3 known to have a left sided inguinal hernia presented to the Emergency department with two weeks of intermittent suprapubic tenderness, dysuria, frequency, urgency, frothy urine as well as nausea and vomiting. Workup on admission revealed an elevated creatinine of $2.8 \mathrm{mg} / \mathrm{dl}$ from a baseline of $1.5 \mathrm{mg} / \mathrm{dl}$, with leukocytosis of 7000 . Urine analysis was performed that revealed large leukocyte esterase, urine WBC greater

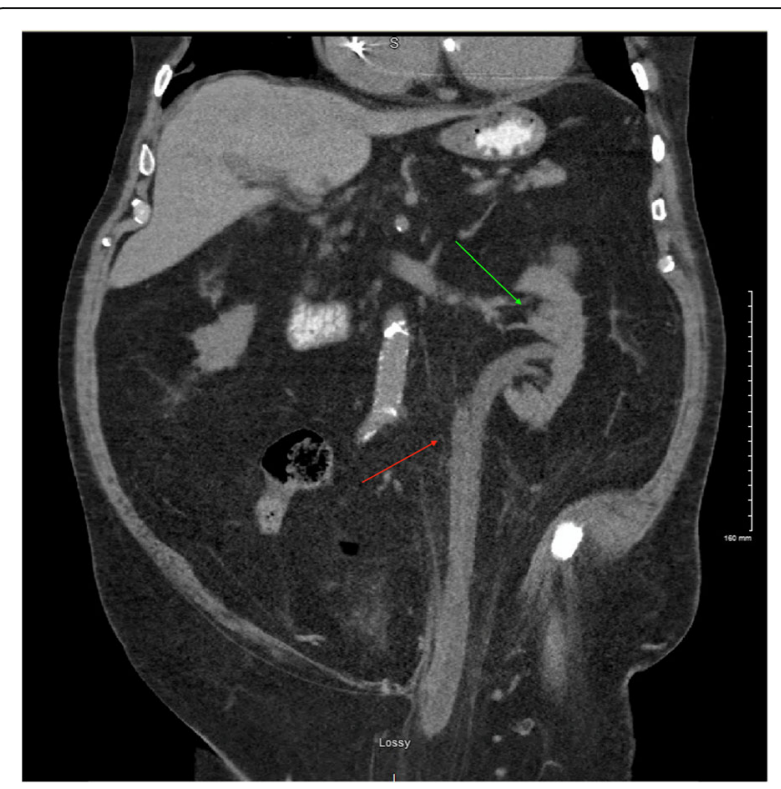

Fig. 1 CT scan of the abdomen and pelvis showing the hydroureternephrosis. (Green arrow: Hydronephrosis, Red arrow: ureteronephrosis)

180, and white blood cell clumps. The patient was diagnosed with acute kidney injury as well as a urinary tract infection. Computed tomography of the abdomen and pelvis revealed duplicated left sided pelvis and ureters with the left inguinal hernia containing the ureters with cystic ureteral dilation within the herniation sac as well as moderate left hydroureteronephrosis (Figs. 1 and 2). The patient was managed with volume repletion and

Table 1 Table showing Case reports in literature describing ureteroinguinal hernia in transplant vs native kidneys with a single or double collecting system, findings on imaging as well as the modality of management

\begin{tabular}{|c|c|c|c|c|}
\hline Authors & Collecting System & Kidney & Imaging Finding & Management \\
\hline He et al. [4] & Single & Native & Left Hydrourertero-nephrosis & Nephro-ureteral stent \\
\hline Hong et al. [5] & Single & Native & Left Hydrourertero-nephrosis & Conservative \\
\hline Lu et al. [6] & Single & Native & Right Hydrourertero-nephrosis & Conservative \\
\hline Eilber et al. [7] & Single & Native & Right Hydrourertero-nephrosis & Conservative \\
\hline Sidqi et al. [8] & Single & Native & Left Uretero-nephrosis & Lichtenstein repair \\
\hline Yahya et al. [9] & Single & Native & Right Hydrourertero-nephrosis & $\begin{array}{l}\text { Lichtenstein repair } \\
\text { Nephro-ureteral stent }\end{array}$ \\
\hline Otani et al. [10] & Single & Transplant & Right hydronephrosis & Nephro-ureteral stent \\
\hline Furtado et al. [11] & Single & Transplant & Left Hydrourertero-nephrosis & Hernia Repair \\
\hline Weingarten et al. [12] & Single & Transplant & Left Hydronephrosis & $\begin{array}{l}\text { Nephro-ureteral catheter } \\
\text { Hernia Repair }\end{array}$ \\
\hline Osman et al. [13] & Single & Transplant & Right Hydrourertero-nephrosis & $\begin{array}{l}\text { Hernioplasty } \\
\text { Nephrostomy tube }\end{array}$ \\
\hline Abu-areda et al. [14] & Single & Transplant & Right Hydrourertero-nephrosis & Nephrostomy tube \\
\hline Won et al. [15] & Single & Native & Pelvic-ureteric junction obstruction & Conservative \\
\hline Malde et al. [16] & Single & Native & Left Hydrourertero-nephrosis & Mesh Hernia Repair \\
\hline Sanchez et al. [17] & Single & Transplant & Right Hydrourertero-nephrosis & Hernioplasty \\
\hline
\end{tabular}




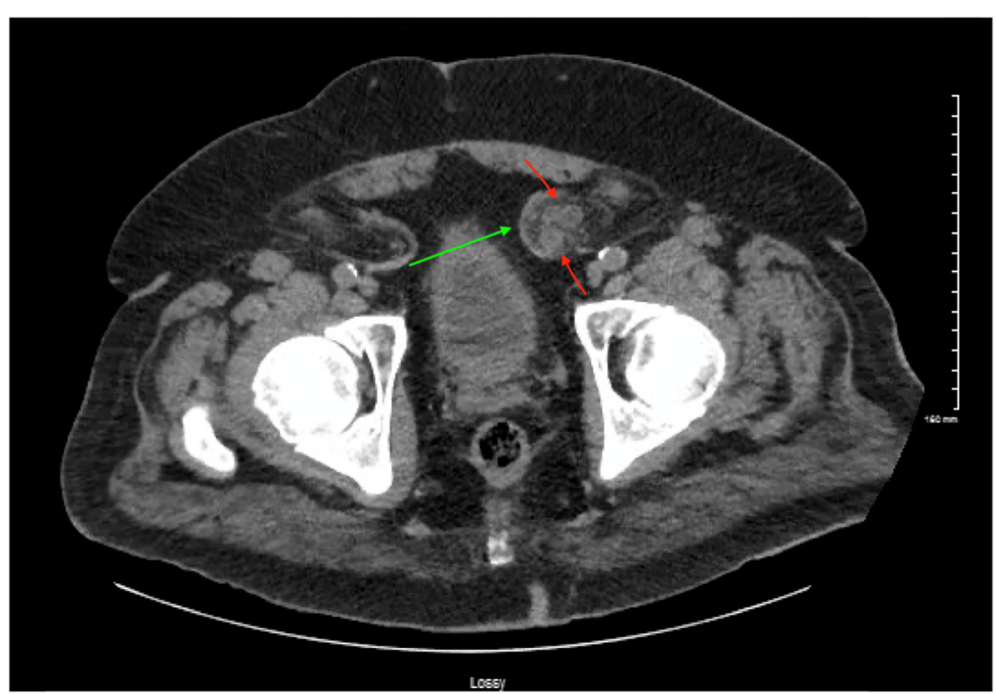

Fig. 2 CT scan of the abdomen and pelvis showing the uretero-inguinal hernia involving duplicated ureters (Green arrow: Hernia, Red arrow: Two ureters)

antibiotics for his urinary tract infection. There was some improvement in kidney function although not to his previous baseline. He was discharged with an outpatient urology follow up and was subsequently readmitted for an elective paraperitoneal inguinal hernia repair with a Kumpe catheter placement up to the left kidney externalizing through the urethral meatus.

When it comes to the inguinal hernia repair, a large portion of the herniated extraperitoneal fat was freed from its incarcerated position in the scrotum and then dissected back to the internal ring. A typical mesh repair was not done in order to avoid placing the mesh in direct contact with the ureter causing erosions as well as ureteral structuring further down the line. Thus, the internal ring was primarily closed first to maintain the ureter in a reduced position deep to the ring then a Lichtenstein repair was done using a polypropelene patch that was sutured to the tissues overlying the pubic tubercle medially to the shelving edge of the inguinal ligament inferiorly and to the conjoined tendon superiorly, laterally the arms of the patch were passed around the spermatic cord at the internal ring and sutured together and to the tissue lateral to the internal ring.

Following the surgery, he had recovery of kidney function to the previous baseline serum creatinine of $1.5 \mathrm{mg} /$ dl. (Table 2) (Fig. 3).

Table 2 Table showing Creatinine ( $\mathrm{Cr}$ : $\mathrm{mg} / \mathrm{dL}$ ) as an indication of kidney function over time (prior to the operation and post operation) POD: post-operative day. PrOD: Pre-operative day

\begin{tabular}{lcccccc}
\hline Days & PrOD & POD1 & POD2 & POD3 & POD4 & POD5 \\
\hline $\mathrm{Cr}(\mathrm{mg} / \mathrm{dL})$ & 2.8 & 2.2 & 1.75 & 1.65 & 1.5 & 1.43 \\
\hline
\end{tabular}

\section{Discussion and conclusion}

Ureteral development begins in fetus at the age of four weeks with the ureteral bud branching from the mesonephric duct [18]. The ureteric bud is responsible for the formation of the collecting system. If two ureteral buds arise, the caudal ureter drains the lower pole and the cephalic ureter drains the upper pole [19]. Patients usually present in childhood with recurrent UTIs, flank pain, incontinence and hematuria [20]. However, diagnosis can be made in rare instances during adulthood when duplex collecting systems are usually found incidentally on abdominal imaging or during surgery [21-23].

Uretral herniation can occur at different sites including inguinal, femoral, sciatic, thoracic and parailiac [24, 25]. Uretero-inguinal hernias have been reported as a

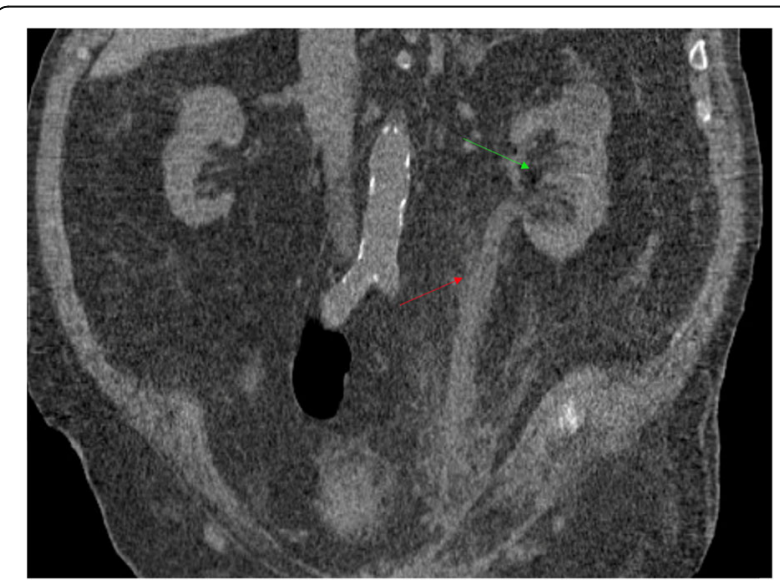

Fig. $3 \mathrm{CT}$ scan of the abdomen and pelvis post-operation day 20 showing improvement in hydroureternephrosis. (Green arrow: Hydronephrosis, Red arrow: ureteronephrosis) 
common complication of renal transplant [26].However, uretero-inguinal hernias in native kidneys are considered an uncommon finding. They are divided into two types: the paraperitoneal or extraperitoneal with paraperitoneal accounting for majority of cases [6,27].

A paraperitoneal hernia occurs when the ureter is adherent to the posterior peritoneum and is herniated alongside the peritoneal sac into the inguinal canal. It is a sliding type of hernia thought to be caused by traction of the underlying structures or adhesions that attach the ureter to the posterior peritoneum. This type of herniation is often accompanied by herniation of other organs such as the colon [15].

On the other hand, extraperitoneal herniation is herniation of the ureter without the peritoneal sac. It is theorized to be due to a congenital embryonic defect that resulted in the fusion of the ureter and the genitoinguinal ligament due to the failure of separation of the ureteric bud from the wolffian duct $[26,28]$. However, one case report attributed the formation of extraperitoneal ureteral hernia to adhesions from a previous hernia repair [29].

Uretero-inguinal hernias can potentially cause obstructive uropathy and in some cases lead to kidney failure if left undiagnosed. Further, if undiagnosed, iatrogenic ureteral injury can occur during hernia repair [30].

Obesity as well as deficiency in collagen synthesis are risk factors for ureteral hernias. These hernias are more frequent on the right side compared to the left due to differences in fascia of Toldt morphology [30].

Ultrasound is the ideal first line imaging modality to assess the upper urinary tract as it can identify hydronephrosis as well as the integrity of the proximal ureter. However, ultrasound of the urinary tract does not routinely include assessment of the inguinal orifices making the tracking of the ureter in the retroperitoneal space a challenge. Cross-sectional imaging (CT scan or MRI) are more reliable for identification of the site and etiology of urinary tract obstruction and can allow identification of the site of herniation as well as anatomical classification with CT remaining more easily accessible between the two modalities.

Herniorrhaphy is considered the treatment modality for uretero-inguinal hernias causing obstructive symptoms [7]. If during imaging, an obstructive uropathy is observed, a nephroureteral stent or nephrostomy tube can be inserted to protect the ureter as well as relieve the obstruction, respectively [4].

A uretero-inguinal hernia is a rare condition that can potentially lead to obstructive uropathy. CT is currently the modality of choice for identification, diagnosis as well as anatomical classification of the hernia and its possible complications. In this case report, we describe a unique uretero-inguinal hernia involving a duplicated ureter causing obstructive uropathy. Recognizing such an entity is important in identifying causes of acute kidney injury and preventing surgical complications.

\section{Abbreviations}

CT scan: Computerized Tomography scan; MRI: Magnetic Resonance Imaging; POD: post-operative day; PrOD: Pre-operative day; Cr: Creatinine

\section{Acknowledgments}

Not applicable.

\section{Authors' contributions}

CEM and HW were the primary team taking care of the patient and contributed in writing this article. $\mathrm{LH}$ reviewed the literature and contributed in writing the manuscript. FYL and KF followed up on the patient post operation and contributed in writing as well. VB is the attending physician who supervised, contributed to and guided us while writing this manuscript. All authors approved the final version of the submitted manuscript.

\section{Funding}

Funding information is not applicable.

\section{Availability of data and materials}

Data sharing is not applicable to this article, as no datasets were generated or analyzed for the purpose of the following study.

Ethics approval and consent to participate

Not applicable.

\section{Consent for publication}

The patient has signed the consent form to publish the as detailed in editorial policies on the BMC urology website and is available for review by the journal editor.

\section{Competing interests}

The authors declare that they have no competing interests.

Received: 12 March 2020 Accepted: 22 June 2020

Published online: 01 July 2020

\section{References}

1. Dabbas N, Adams K, Pearson K, Royle G. Frequency of abdominal wall hernias: is classical teaching out of date?. JRSM Short Rep. 2011;2(1):5. https://doi.org/10.1258/shorts.2010.010071.

2. Kark AE, Kurzer M. Groin hernias in women. Hernia. 2008;12(3):267-270. https://doi.org/10.1007/s10029-007-0330-4.

3. Malek RS, Kelalis PP, Stickler GB, Burke EC. Observations on ureteral ectopy in children. J Urol. 1972;107(2):308-313. https://doi.org/10.1016/s00225347(17)61012-7.

4. He L, Herts BR, Wang W. Paraperitoneal ureteroinguinal hernia. J Urol. 2013; 190(5):1903-1904. https://doi.org/10.1016/j.juro.2013.08.005.

5. Hong LE, Tan C, Li J. Obstructive Uropathy Secondary to Uretero-inguinal Hernia. J Clin Imaging Sci. 2015;5:33. https://doi.org/10.4103/2156-7514. 159448

6. Lu A, Burstein J. Paraperitoneal inguinal hernia of ureter. J Radiol Case Rep. 2012;6:22-6

7. Eilber KS, Freedland SJ, Rajfer J. Obstructive Uropathy secondary to Ureteroinguinal herniation. Rev Urol. 2001;3:207-8.

8. Sidiqi MM, Menezes $G$. Asymptomatic herniation of ureter in the routine inguinal hernia: A dangerous trap for general surgeons. Int J Surg Case Rep. 2018;49:244-246. https://doi.org/10.1016/j.jjscr.2018.07.013.

9. Yahya Z, Al-habbal $Y$, Hassen S. Ureteral inguinal hernia: an uncommon trap for general surgeons. Case Reports. 2017;2017:bcr2017219288.

10. Otani LH, et al. Sonographic diagnosis of a ureteral inguinal hernia in a renal transplant. J Ultrasound Med. 2008:27(12):1759-65.

11. Furtado CD, Sirlin C, Precht A, et al. Unusual cause of ureteral obstruction in transplant kidney. Abdom Imaging. 2006;31:379-82.

12. Weingarten $\mathrm{KE}$, et al. Obturator herniation of the ureter in a renal transplant recipient causing hydronephrosis: perioperative percutaneous management. J Vasc Interv Radiol. 1996;7(6):939-41.

13. Osman $Y$, et al. Sliding hernia containing the ureter - a rare cause of graft hydroureteronephrosis: a case report. Transplant Proceed. 2004;36:5. 
14. Areda MA, Bailey CR, O'Mara D, Weiss CR. Transplant uretero-inguinal hernia resulting in urosepsis. Radiol Case Rep. 2018;14(1):14-7.

15. Won ACM, Testa G. Chronic obstructive uropathy due to uretero-inguinal hernia: a case report. Int J Surg Case Rep. 2012;3:379-81.

16. Malde S, Bilagi P, Marsh H. Obstructive uropathy due to uretero-inguinal hernia: an uncommon occurrence. Indian J Urol. 2013;29(4):355-6.

17. Sánchez ASS, Tebar JC, Martín MS, Bachs JMG, Moreno MJD, Navarro HP, Rodríguez JAV. Obstructive Uropathy secondary to ureteral herniation in a pediatric En Bloc renal graft. Am J Transplant. 2005;5:2074-7.

18. Brehmer B, Makris A, Jakse G. Laparoscopic heminephrectomy and resection of ectopic ureter in an adult. Urol Int. 2007;79:280-3.

19. Lavallée $\mathrm{G}$, et al. Obstructed duplex kidney in an adult: ultrasonic evaluation. J Clin Ultrasound JCU. 1985;13:281-3.

20. Gao Z, Wu J, Lin C, Men C. Transperitoneal laparoscopic heminephrectomy in duplex kidney: our initial experience. Urology. 2011;77:231-6.

21. Balén EM, Pardo F, Lecumberri FJ, Longo J. Giant megalo-ureter and duplex kidney in an asymptomatic adult. Scand J Urol Nephrol. 1997;31:413-6.

22. Mahajan NN, Sahay S, Kale A, Nasre M. Unilateral upper-pole giant hydroureter in a duplex renal system: an incidental finding in cesarean section. Arch Gynecol Obstet. 2008;278:149-51.

23. Zissin $R$, et al. Renal duplication with associated complications in adults: $C T$ findings in 26 cases. Clin Radiol. 2001;56:58-63.

24. Hwang CM, Miller FH, Dalton DP, Hartz WH. Accidental ureteral ligation during an inguinal hernia repair of patient with crossed fused renal ectopia. Clin Imaging. 2002;26:306-8.

25. Giglio M, et al. Scrotal extraperitoneal hernia of the ureter: case report and literature review. Urol Int. 2001;66:166-8.

26. Odisho AY, Freise CE, Tomlanovich SJ, Vagefi PA. Inguinal herniation of a transplant ureter. Kidney Int. 2010;78:115.

27. Bertolaccini L, Giacomelli G, Bozzo R, Gastaldi L, Moroni M. Inguino-scrotal hernia of a double district ureter: case report and literature review. Hernia. 2005;9:291-3.

28. Peters CA, Schlussel RN, Mendelsohn C. Ectopic ureter, ureterocele, and ureteral anomalies. In: Wein A.J., editor. Campbell-Walsh Urology. 10th ed. Philadelphia: Saunders Elsevier. Chap 117; 2012.

29. Golgor E, Stroszczynski C, Froehner M. Extraperitoneal inguinoscrotal herniation of the ureter: a rare case of recurrence after hernia repair. Urol Int. 2009;83:113-5.

30. Giuly J, François GF, Giuly D, Leroux C, Nguyen-Cat RR. Intrascrotal hernia of the ureter and fatty hernia. Hernia. 2003;7:47-9.

\section{Publisher's Note}

Springer Nature remains neutral with regard to jurisdictional claims in published maps and institutional affiliations.

Ready to submit your research? Choose BMC and benefit from:

- fast, convenient online submission

- thorough peer review by experienced researchers in your field

- rapid publication on acceptance

- support for research data, including large and complex data types

- gold Open Access which fosters wider collaboration and increased citations

- maximum visibility for your research: over $100 \mathrm{M}$ website views per year

At $\mathrm{BMC}$, research is always in progress.

Learn more biomedcentral.com/submissions 